DOI https://doi.org/10.36059/978-966-397-158-2/175-190

\title{
FEATURES OF POLITICAL STABILITY IN UKRAINE IN THE CONDITIONS OF POLITICAL TRANSIT
}

\section{Kozminykh A. V.}

\section{INTRODUCTION}

The study of the features of political stability in Ukraine in the conditions of political transit requires an integrated study. For this purpose it is important to define the concepts and components of political stability, to consider the phenomenon of political transit, its characteristics and peculiarities, as well as to determine what place Ukraine occupies in these processes at the present stage of its development. It is through this knowledge that we can analyze the features of political stability in our country and determine the effectiveness of the mechanisms designed to provide it.

Many scholars have approached the study of the problem of political stability at different times, which can be roughly divided into several groups. The first group of researchers may include scholars studying the theoretical and methodological features of transit processes, in particular modernization (W. Beck, R. Bendix, S. Black, M. Levy, U. Rostow, S. Huntington, P. Stompka, S. Eisenstadt, R. Inglehart, T. Carl, T. Carothers, A. Croissant, X. Linz, S. Lipset, B. Merkel, A. Perevorsky, D. Rostow, A. Stepan, etc.) and transformation (I. O. Batanov, V. Ya. Gelman, T. I. Zaslavskaya, V. V. Lokos, V. O. Yadov, I. S. Yazhborovska, and others).

Another group includes works devoted to the formation of new and functioning of traditional institutions in the conditions of transformation of the political system of society (M.G. Anokhin, L.E. Blacher, S.V. Volodenkov, A.Yu. Zudin, I.M. Igoshin, S.G. Kirdina, A. Rybakov and others). Many theoretical propositions and questions of applied political science were investigated by M.G. Anokhin, A.V. Krutov, L.V. Postnikov, Yu. Semygin, A.F. Shabrov.

The third group is formed by studies that discuss the features of political transformation in the post-Soviet space and Ukraine (V. Bani, R. Darendorf, G. O’Donnell, I.B. Kiyanka, N.O. Latigina, M. McFall, K. Offe, C. White, A. Schleifer and others). 
It should be noted that, despite the considerable amount of research in this field, they all have sufficiently noticeable segmentation, which lacks the most comprehensive approach to studying the features of political stability in Ukraine in the context of political transit.

Therefore, the purpose of the study is to identify and analyze mechanisms that can effectively ensure the political stability of the modern Ukrainian state in the current political transit conditions.

First of all, in order to study the features of political stability in Ukraine in the context of political transit, it is necessary to clarify the concepts of political stability, identify the factors that influence this phenomenon, as well as those criteria that allow us to assign a particular political system to the category of stable or unstable.

The need for political stability is a priority for any state, regardless of political regime, economic development, historical or cultural factors. Political stability is often found in the major constitutional documents of many countries of the world as a priority area of state policy in the field of national security. Maintaining the stability of the political system is one of the guarantees of the security of the state, which is able to respond adequately to the challenges and threats to its existence, both domestically and externally.

Political stability is derived from the influence of many factors on the political system of society: the trust of citizens to the authorities, the consensus of the elites in the directions of the country's development, the progressive economic growth, social well-being, the type of political culture, a strong state, constructive inter-ethnic and inter-denominational relations, etc. Moreover, the full development of the political system requires stability in all these areas.

\section{Political stability in conditions of political transit and the main mechanisms of its support}

Despite the fact that the term «political stability» is quite widespread and is very common in the scientific literature, there is still no common position among scientists to define it. In order not to dwell for a long time on the discussions on the essence of political stability, it should be noted that regardless of the regime, the type of legitimacy of power and other factors, it is characterized by a balanced state, both in domestic and foreign relations.

In the most general sense, political stability should be understood to mean such a state of the political system of society, which preserves and reproduces the essential identity of such a system, the stability of the political regime and forms of government, the protection of the 
constitutional order in the country, as well as the preservation of civil peace and understanding in the country.

We emphasize an important characteristic - the notion of political stability reflects not the static but the dynamic state of political structures and relations. It allows the political system to retain its basic parameters and characteristics over time, preserving its basic characteristics and trends of political development, and without being subjected to destabilizing influences. Let us agree with the opinion of some authors that political stability should be understood as the stability of the political system, which expresses the fundamental interests of the main social groups and ensures the socio-political stability of society and the absence of acute social and political conflicts in it ${ }^{1}$.

In a stable political system, there is a certain balance in political and social forces, which makes it possible to use political mechanisms effectively, both to maintain the status quo and for progressive development and to carry out reforms and transformations that are positive for society. At the same time, it would be justified to say that the lack of such a balance in the political space either leads to destabilization or is a sign of pre-existing instability of the political system.

The destabilizing aspects of the political system can be divided into the following types: the systematic type of destabilization implies violations in the system of regularities and tendencies of holistic, complex development and stability of all institutions of the political system; cognitive appearance is based on the distribution of powers between individuals, where destabilizing factors operate contrary to the reasonable and rational distribution of such powers, and aimed at depriving such entities or any of them of complete information about events and processes occurring in the community leads to a violation of the mechanism of decision-making and coordination at different levels of political governance in order to stabilize the situation in the system; functional kind of destabilization occurs in the sphere of realization of powers, plans and programs of subjects of the political system and is aimed at occurrence of possible and real results from destabilization of political activity of these subjects in society.

The criterion of political stability is the level of coherence of political interests of different social groups of society, the state and all citizens. It is characterized by quantitative and qualitative parameters that respond to deviations from the equilibrium values of the main indicators.

1 Грищенко Д.Ю. Политическая безопасность современного Российского государства: состояние и механизм обеспечения : автореф. дис... канд. полит. наук: 23.00.02. Владимир, 2008. С. 7. 
We can consider such attributes as systemic attributes of political stability; positive development dynamics; absence of exacerbation of processes; the active role of civil society in ongoing processes; predictability of evolutionary processes.

Political stability is an important dimension of social stability, which implies a state of correlation between social groups and political forces, in which none of these forces can significantly change the political system in their interests, which ensures its status quo ${ }^{2}$. This balance is maintained through a complex mechanism of internal and external links between the elements of the political system and the political system itself. Thus, in the first case it is about equilibrium of constituents of political system and interaction between its institutions, and in the second - interaction of the whole political system with other systems of society ${ }^{3}$.

Thus, the state of political stability is intended, in particular, to ensure an adequate level of political security in a society, which should be understood as the absence of severe socio-political conflicts in the society, or constant and at the same time effective actions, first of all, of political power, to minimize the destructive influence on a society of such conflicts ${ }^{4}$. It is the implementation of a prudent policy on existing conflicts, both inside and outside the system, that make it possible to strike a balance of the political system, facilitate its further development and conduct civilized dialogue between the political forces of the country, and thus ensure the stability of the state as a system.

In terms of factors affecting the state of stability, as an important qualitative characteristic of the political system, which is ensured by the well-established interconnections between all its elements, we can distinguish between objective and subjective factors. Objective factors of political stability include: the resilience of political institutions and the effectiveness of the system of separation of powers, the political culture of a society that supports the regime. To the subjective - the effectiveness and legitimacy of power in society ${ }^{5}$.

\footnotetext{
2 Яворський М. Політична стабільність: сутність та основні підходи до класифікації. Політичні науки. 2017.Vol. 3. № 1. С. 62.

${ }^{3}$ Карл Т.Л., Шмиттер Ф. Демократизация: концепты, постулаты, гипотезы. Полис. 2004. № 4. С. 11.

4 Грищенко Д.Ю. Политическая безопасность современного Российского государства: состояние и механизм обеспечения : автореф. дис... канд. полит. наук: 23.00.02. Владимир, 2008. С. 11.

${ }^{5}$ Савин С.Д. Политическая стабильность в изменяющемся обществе : автореф. дис... канд. соц. н.: 23.00.02. СПб, 2003. С. 15.
} 
Undoubtedly, the central entity in the process of ensuring political stability is the state and its institutions. The nature of political stability in a country is largely determined by the political regime that exists in it (democratic, authoritarian, etc.). And depending on this, the mechanisms that support such stability differ.

For example, authoritarian and totalitarian regimes have a peculiar stability that allows such states to maintain their integrity, even under extremely difficult conditions. At the same time, their inherent mechanisms of maintaining the state of political stability are oriented towards the formation of a closed socially homogeneous society, where the regulation of any relations is ensured by repression, violence aimed at eliminating any existing or potential opposition. Such stability is unproductive because it leads to depression and political stagnation and leads to the collapse of the political system. That is, it is about stagnant stability.

At the same time, a democratic society is an open system that is able to adapt relatively quickly to changes in the internal and external environment. Therefore, such a state is inherently dynamic and includes political pluralism and multiparty politics, where competition in the struggle for political power is realized within the framework of generally accepted democratic legislative rules. The openness of a democratic society's political system enables it to adapt relatively quickly to changes in the internal and external environment by responding swiftly, adequately and effectively to its challenges. Such stability is dynamic, it can be called alive, constructive and guaranteeing the self-reproduction of democratic regimes. Thus, the phenomenon of political stability is characterized by the existing mechanism of adaptation of the political system to the conditions of functioning of the society and its peculiarities, thus providing the most optimal conditions for the normal functioning of the political system.

It should be noted that a stable democratic state is characterized by a number of defining features: a sense of belonging to the nation by the population of that state; stability of forms of government with the simultaneous guarantee of legal change of power, which does not allow usurpation of power in one hand. In a broad sense, it is a way of replacing or transferring political power from one individual (government or regime) to other relevant actors, which helps to avoid crises and keeps the process under control; gradual and orderly rotation of ruling elites; the existence of a system of checks and balances, which ensures a balance in the power structure and prevents abuse; multiparty and effective opposition; the presence of a large middle class. 
The aforementioned factors of political stability are interrelated because instability of one of them can lead to instability of the whole country.

Important in this context is the analysis of the theory of political transit, which in its essence represents the transition of society from one state to another, namely from authoritarian or totalitarian political system of the country to democracy, and socio-economic sense - from monopolistic, isolated, controlled mainly state, economy to market economy ${ }^{6}$.

The classical theory of three «waves of democratization» by S. Huntington, which is a group of transitions from undemocratic to democratic regimes that take place over a period of time, according to which democratization is regarded as a global process, made a significant impact on the development of political transit theory ${ }^{7}$.

Democratic transit takes place over a period of time, during which the state-political system of the country and society itself undergoes fundamental transformation and dramatic changes. In addition, this process is characterized by a two-phase «stabilization / destabilization» dynamic, and for the successful completion of the transit process it is crucial that stabilization methods and means contribute to the promotion of democratic principles in the organization of social and political life.

It is important for our study to take into account the fact that there is no consensus among researchers as to where the political transit process should go. The classic view is that of democracy. However, recent researchers are no longer uniquely apprehending its ultimate goal. After all, in some countries, the population will calmly respond to changing conditions, justifying the ultimate goal of transition, and in others, quite quickly disappointment occurs in the process ${ }^{8}$, because of the collapse of illusions about democracy as a path of common prosperity, because the process of democratization is often accompanied by poverty for a large part of the population. The inability of young and not yet established democratic regimes to satisfy the economic interests of the poor will often threaten the entire democratization process.

Thus, transit processes do not always lead to the formation of a «standard» liberal democracy ${ }^{9}$, and during transit, a hybrid political regime may emerge, where democratic and authoritarian elements are closely intertwined, and the transition to consolidated democracy does not occur.

${ }^{6}$ Балаян А. Политический транзит в России: особенности и перспективы на современном этапе. 2006. URL: https://forum-msk.org/material/society/11846.html

${ }^{7}$ Демократія : Антологія / упоряд. О. Проценко. Київ: Смолоскип, 2005. С. 657.

8 Балаян А. Политический транзит в России: особенности и перспективы на современном этапе. 2006. URL: https://forum-msk.org/material/society/11846.html 
Needless to say, «democracy is more of a culture than a system of institutions ... Thus, democracy is based on the slow acquisition of tolerance and awareness of its borders: because a democratic government cannot solve all issues and appreciate its nature faster, than the results of activities that are not necessarily better in all respects than under illiberal rule» ${ }^{9}$.

All these factors lead to the great complexity of effectively ensuring the state of political stability in transit political systems in general and in Ukraine, in particular, because the ongoing processes are characterized by dynamic changes in the political system and the absence of established democratic mechanisms that would be maintained from within and reproduce themselves, and the complete absence of any guarantee of successful completion of the political transit process ${ }^{10}$.

Thus, it is necessary to turn to the consideration of the problem of the state stability as a key issue in ensuring the stability of the political system as a whole. As important forms of systemic counteraction to contemporary threats to political stability are measures to increase the resilience of the state to destructive information influence, economic and military weakening of the country, exacerbation of social contradictions in society and strategies to counter external, internal and cross-border threats ${ }^{11}$.

Increasing the stability of the state is achieved through the implementation of a system of measures and actions of state bodies, local self-government bodies and public organizations, aimed at ensuring the legitimacy of the authorities, preserving internal public, interethnic and inter-confessional peace, territorial integrity and protection of sovereignty at the national level, internal and cross-border threats.

Of course, the achievement of ideal political stability is generally utopian, since constructive political stability is not absolute. Full stability is impossible, as social development is devoid of any conflict, because they are an indispensable driving force for progress. In general, oddly enough, too high a degree of resilience of any system, including a political one, diminishes its viability. Such excessive stability may be a consequence of the hidden resistance to change by such a system. That is, the inability of the political system to adapt to change can be hidden here, which inevitably leads to the death of the system. After all, the normal political process

${ }^{9}$ Демократія : Антологія / упоряд. О. Проценко. Київ: Смолоскип, 2005. С. 16-17.

${ }_{10}$ Бокало Н., Трохимчик С. Проблеми та перспективи демократизації в країнах центрально-східної Європи (на прикладі Вишеградської четвірки). Львів: Львів. нац. ун-т ім. І.Франка, 2000. С. 48.

11 Семченков А.С. Противодействие современным угрозам политической стабильности в системе обеспечения национальной безопасности России: автореф. дис... д. полит. наук : 23.00.02. Москва. 2012. С. 24. 
includes the continuous improvement of the political system, due to its adjustment in accordance with changes occurring in all spheres of public life. And if such improvement is evolutionary, without rigid political crises, then we can assume that the political system is stable. It is this stability that should be sought as it meets the requirements of a stable and normal functioning of the system.

So let's look at the main factors and conditions that make it possible to achieve political stability in the state: the legitimacy of the political regime in the state and its legality; maintaining a high level of public confidence in the authorities through overcoming bureaucratic obstacles and corruption within the country; the ability of the political system to function effectively and respond as quickly as possible to external and internal challenges; the existence of an effective legal system in the state; guaranteeing human rights and freedoms, as well as maintaining the public's desire to participate in the political life of the country; finding the maximum balance between the norms of morality and law in society; maintaining the optimal class structure of society; prevention of acute socio-ethnic and religious conflicts within the state; effective political communication and interaction of the authorities with the people; the use by the authorities of international experience in state and political development ${ }^{12}$.

Obviously, the study of political stability is impossible without taking into account such fundamental properties of political systems as integrity, stability, dynamic equilibrium, organization, activity and informativeness. An extremely important indicator of political stability is also the ability of the system to reproduce its integrity with all its relations and relations between the elements and the fulfillment of their responsibilities. Therefore, we can attribute the system's ability to constantly rebuilding its integrity to an important feature of the phenomenon of political stability.

It should be noted that at the present stage maintaining a state of political stability, besides the influence of traditional elements (state, parties, mass media, etc.), also requires consideration of a number of other factors, processes and phenomena (transitional processes, conflicts, regional integration, new political identification political finance, party building processes, democratization, transitology and more).

12 Семченков А.С. Противодействие современным угрозам политической стабильности в системе обеспечения национальной безопасности России: автореф. дис... д. полит. наук : 23.00.02. Москва. 2012. С. 27. 


\section{Political stability and current transitive processes: the Ukrainian experience}

The use of universal postulates and schemes requires special care, as each transit country has its own specificity, which requires a careful and comprehensive analysis of national experience, which makes the process of regime transformation separate, unique and different from other systems. But in general terms, the transit processes experienced by the Ukrainian political system can obviously be included in the «third wave of democratization» by S. Huntington ${ }^{13}$, and, despite the significant differences in socio-political and economic processes, consideration of this group of countries is of some theoretical and practical interest for Ukraine: in the process of democratic transit, the states in which the establishment of democratic institutions was accompanied by the gradual formation of political and cultural values in the society are the most successful; transformations in the economic and political spheres are characterized by increased conflict and the risk of establishing hybrid regimes; democratic values are positively perceived mainly by citizens of those countries that successfully solve economic and social issues. Conversely, insufficient attention to socio-economic problems complicate the movement of states towards democratization. The unstable, unconsolidated character of the political systems formed is characteristic of those countries where economic and socio-cultural conditions were not necessary, and the process of democratization was only a consequence of the struggle for power of individual elites and political groups; there are no examples of stable democracies in states without market and private property. A market economy ensures the autonomy of the individual, protects him from total state control, stimulates the development of qualities necessary for democracy, such as the desire for freedom, responsibility, enterprise; the country's geopolitical location is extremely important for democratic change. Countries located in areas of «traditional democracy» have significant benefits and a high chance of accelerating political reform. However, the purely mechanical transfer to the countries of the «new democracies» of those methods that have played a decisive role in the democratization of the political system of the «old democracies» countries leads to the fact that in the «new democracies» countries political transit becomes variable or protracted ${ }^{14}$.

13 Хантингтон С. Третья волна. Демократизация в конце XX века. Москва: РОССПЭН, 2003. С. 57

14 Хантингтон С. Третья волна. Демократизация в конце XX века. Москва: РОССПЭН, 2003. С. 313. 
An analysis of the regional experience of democratic transit in the countries of the «third wave of democratization» shows that the rapid pace of political change is characteristic of those countries in which the processes of democratization were caused by a complex of internal and external causes, mass need and participation in these processes by the general population and which had institutional prerequisites. The unstable, unconsolidated nature of the established political regimes is inherent in those countries that did not have the necessary economic and socio-cultural conditions at the time of the beginning of democratic transformations, and the process of democratization is only a consequence of the struggle for elite power and political groups. It is also important to take into account the specificity of the Ukrainian mentality and cultural diversity with countries where transit is more rapid (for many reasons, Eastern Europe, Baltic countries), where old values and relationships are preserved while changing the whole way of life.

The position of modern countries of democratic transit to the model of «democracy with defects» (including Ukraine) is interesting) ${ }^{15}$. Political scientists V. Merkel and A. Croissant identify three varieties of «democracies with defects»: «democracy with exceptions», in which a large segment of the population is deprived of the right to participate in elections because of certain characteristics (racial, age, etc.); «Democracy with enclaves, $\gg$ in which certain spheres of public life are brought out of democratic control; «Unbalanced democracy» in which the actions of the executive are not correlated with parliament and the judiciary.

Thus, when analyzing mechanisms for maintaining political stability in Ukraine in the context of political transit, we should pay special attention to the following characteristics:

There is a marked change in the stabilization / destabilization phases for the Ukrainian political system. As noted earlier, the alternation of the «stabilization / destabilization» phases is a characteristic feature of any political transit process, where the state of political stability of the system corresponds to its antipode - the state of instability, the period of lack of balance between different elements of the political system. In Ukraine, there is a noticeable trend towards deepening and increasing the duration of the destabilization phases compared to the periods of stability. However, it should be noted that in the «stabilization / destabilization» phases of the political process, the destabilization phase is not only a threat but also a

${ }^{15}$ Covington C. Smith E. Dynamics of Democracy. Madison-Sydney: Brown\&Benchmark, 1995. P. 10. 
rather interesting time of opportunity when ineffective mechanisms operating in the political system can be detected and changed;

It is worth noting the positive orientation of the pace and scale of political transformation and reform in other areas. Ukraine has been sufficiently consistent in reforming many spheres of political, economic and social life. However, the many disadvantages of these processes cannot be ignored. So, for political and state stability, the presence of a strong middle class, which is only emerging in Ukraine, is of great importance. Also, until now, Ukraine does not have effective government instruments to protect foreign investors, which is an extremely important issue for potential investors, and therefore to ensure the financial component of political stability in Ukraine. These factors create unfavorable conditions for both domestic entrepreneurs and foreign investors;

Ukraine is characterized by the weakness of the processes of formation of democratic institutions of the political system, which is explained, in particular, by the inertia and reaction of the political elite, which does not want to abandon the use of shadow groups of influence because of fears that their rejection will lead to a general loss of positions on the political Olympics of Ukraine, decreases public confidence in government institutions and their representatives, which, in particular, effectively sabotages many political forces and electoral reform;

Let us note the significant increase in the last ten years of the level of political consciousness of the population, as well as the participation of civil society organizations in the political life of Ukraine. We can say that in this aspect today there are factors that contribute to the formation of political stability in Ukraine. It is about the activity of civil society that has begun to feel its strength, as well as the promotion of a truly democratic system by the European Union and International Financial Organizations. These factors counterbalance destabilizing mechanisms, which include considerable inertia of the institutional structure and weakness of the political will of the ruling elite;

The effectiveness of the methods aimed at ensuring political stability in Ukraine is diminished due to an inefficient, corrupt, management system characterized by a clearly insufficient level of professionalism of the judiciary, the weakness of the judicial system, which will be discussed below, the absence of guarantees of private property rights, structural and infrastructural defects, does not provide the dynamic stability necessary for the development and successful implementation of the state in the $21 \mathrm{st}$ century;

Ideological factors: many researchers point to the era of «mediaocracy» (the media authorities), who no longer reflect and interpret reality as much 
as they construct it by their own rules and discretion. And it is quite clear that the Ukrainian media are becoming a kind of weapon in the hands of the authorities, external enemies, as well as other interested parties. Media interference in politics leads to a decrease in the amount of closed information on political decision-making, including through political negotiations. The systematic acquisition of audience information about what is being discussed at interstate meetings creates a picture of the world that determines attitudes towards political figures and even states, and, consequently, the reaction to their actions. Therefore, in Ukraine, as in the whole world, the media are becoming a means of pressure, significantly reducing the effectiveness of traditional methods of conflict resolution, in particular, such as political negotiations. Today, as never before, the issue of the need for special measures is being raised, which will minimize the negative manipulative influence of the media on the political decisionmaking process. Also, the extremely difficult state of social integration of Ukraine is exacerbated by the fact that part of Ukrainian society is under the influence of another state in artificially alienated territories - illegally annexed Crimea and unrecognized republics of Eastern Ukraine. This destabilizing factor has many challenges not only for today but also for the future, the search for answers that is attracting worldwide attention;

Economic factors: today, Ukraine faces many economic problems, including, inter alia, the military conflict in Eastern Ukraine;

Foreign policy factors: external political stability includes at least four parameters: geopolitical, political, foreign economic, military-strategic. In today's world, the first place, along with geopolitical, foreign economic (geoeconomic) activity of state structures, which aims at creating adequate mechanisms for defending the interests of the national business community, supporting the competitiveness of Ukraine's national economy, including all national business, regardless of ownership and capital. What is needed is not so much a radical breakdown and complete denial of national experience as the adjustment of the course to the new realities that are constantly emerging in Ukraine.

The political stability of the Ukrainian political system is significantly influenced by the difference of interests of individuals, social groups, political actors, etc., which objectively causes conflicts of interest within the political system and, as a consequence, the presence of various conflicts and causes for their emergence and, consequently, the possibility of political disturbance of stability in society.

Based on the above methodological prerequisites, let's look at specific factors that can affect political stability in Ukraine. 
Political transit in modern Ukraine should be recognized as incomplete, as we noted, Ukraine is referred to countries with «defective democracy» ${ }^{16}$. The peculiarity of such a model is that elections as a democratic procedure are entrenched, but there is no real opportunity to exercise citizens' rights and freedoms. Therefore, in modern Ukraine, there is a need not only for the modernization of the country's legal and economic system, but also for the creation of modern effective institutions, the formation of an appropriate system of values, sustainable social practices, and it is also important to provide an evolutionary path of development, since another deep phase of destabilization may even end with the collapse of the entire political systems.

The most important characteristic of political transit in Ukraine is the increased level of conflict and the weakness of the mechanisms of their settlement, which is especially dangerous given the high level of social polarization and military conflict into which Ukraine has been involved.

At the present stage, the most important factor in Ukraine's political stability is the state mechanism of preserving the bodies and institutions of the authorities, increasing their authority in the eyes of the population, as well as the search by the existing political institutes of ways of constructively overcoming manifestations of opposition sentiments among the population of the country without bringing them to the stage of «Maidan».

Stability, in turn, does not deny the existence of a conflict field for Ukraine's political system. As we have already noted, it is impossible to avoid conflicts at all, because the human society itself is conflicting in nature, it presents many views, personalities who are drawn into political parties and public organizations representing the interests of certain sections of the population. That is why one-sided political coloring is not allowed in democratic political doctrines, and particular attention is paid to pluralism of opinions and mechanisms of compromise settlement of contradictions.

It should be emphasized that the study of democratic transit in modern Ukraine is not only theoretical, in view of the specificity of the process, but also practical, since it depends largely on the political, economic, social, cultural development of the society, the outcome of the transit in many respects are crucial for the future of the country. The political elite of Ukraine must ensure the stability of the political system by consensus, when the development of political processes is carried out without actual violence, the balanced nature of relations between the main social groups is ensured,

\footnotetext{
${ }^{16}$ Merkel W. Embedded and Defective Democracies. Democratization. 2004. Vol. 11. № 5. P. 48 .
} 
the level of equilibrium is acceptable and the civilized forms of dialogue of the political forces of the country are used in the context of political transit.

\section{CONCLUSIONS}

Thus, it can be argued that the processes taking place in Ukraine today are complex and ambiguous in nature. The stability of our country's political system under transit conditions should be considered in direct connection with the stability of the whole country as a whole and the mechanisms for ensuring such stability that the state has. It is important to take into account the ambiguous events of recent years that indicate a serious threat not only to political stability in Ukraine in terms of political transit, but also to the Ukrainian statehood itself. From where political transit takes us, the nature of change in all spheres of the country's political and socio-economic system depends to a large extent. This does not mean that political transit will not happen, just the outcome may be far from democracy.

It is determined that the political system of Ukraine plays a significant role among the entities providing political stability, which are held by state and local self-government bodies, as they provide mechanisms for supporting political development in the country, and act as legitimate state authorities. An effective mechanism for ensuring political stability should include political and party pluralism, where there is competition between actors in the struggle for political power. The trajectory of European development and the relevant mechanisms for ensuring political stability may become elements of a mechanism that supports political stability in Ukraine.

Contemporary Ukraine is in dire need of new approaches to ensure effectively political stability, which naturally attracts the attention of scientists, politicians and statesmen. Studying and identifying mechanisms that can support political stability in our country has become of paramount importance. In today's Ukraine, the nature of political stability or instability is determined by socio-economic and ideological conflicts, both in society and in the elite environment, and the reasons for this are the ineffectiveness of lawmaking. This is due both to the use of the imperfection of legislation for selfish purposes and to the lack of political will to carry out democratic reforms and to form narrow group interests in business and political groups.

Today, Ukrainian society has undergone a major transformation of its basic political values, which has led to its transition from a totalitarian system of government to a regime of democracy. Then a new wave of crisis phenomena, ethical and moral problems emerged, political struggle intensified. Obviously, the main task of civil society development in Ukraine 
is to ensure constitutional norms and legal regulation that contribute to the emergence of political stability.

\section{SUMMARY}

The article deals with the phenomenon of political stability in transitional political systems. It is determined that political stability should be understood as the stability of the political system, which expresses the fundamental interests of the main social groups and ensures the sociopolitical stability of society and the absence of acute social and political conflicts in it. Political stability implies a dynamic, evolutionary, stable and continuous on the basic characteristics when the development of political processes is carried out without actual violence, there is an adequate form of power conversion (from state to society and back), balanced relations are maintained both within the elite and the elite with other social groups, as well as an acceptable level of balance and civilized forms of dialogue between the political forces of the country. Undoubtedly, the fundamental condition for ensuring political stability in Ukraine is the end of the armed conflict, the return of the captured territories and the achievement of peace and social stability in the country.

\section{REFERENCES}

1. Балаян А. Политический транзит в России: особенности и перспективы на современном этапе. 2006. URL: https://forummsk.org/material/society/11846.html

2. Бокало Н., Трохимчик С. Проблеми та перспективи демократизації в країнах центрально-східної Свропи (на прикладі Вишеградської четвірки). Львів: Львів. нац. ун-т ім. І.Франка, 2000. 68 с.

3. Грищенко Д.Ю. Политическая безопасность современного Российского государства: состояние и механизм обеспечения : автореф. дис... канд. полит. н.: 23.00.02. Владимир, 2008. 26 с.

4. Демократія : Антологія / упоряд. О. Проценко. Київ: Смолоскип, 2005. $1108 \mathrm{c}$.

5. Карл Т.Л., Шмиттер Ф. Демократизация: концепты, постулаты, гипотезы. Полис. 2004. №4. С. 11-14.

6. Кіянка І. Б. Політична стабільність: суть і основні засоби iii досягнення в Україні : автореф. дис. ... канд. політ. наук: 23.00.02. Львів, 2003. $18 \mathrm{c}$.

7. Латигіна Н. А. Демократія : реалії versus утопії. Київ: Київ. нац. торг.-екон. ун-т, 2008. 400 с. 
8. Савин С.Д. Политическая стабильность в изменяющемся обществе : автореф. дис... канд. соц. н.: 23.00.02. СПб, 2003. 29 с.

9. Семченков А.С. Противодействие современным угрозам политической стабильности в системе обеспечения национальной безопасности России: автореф. дис... д. полит. наук : 23.00.02. Москва. 2012. $50 \mathrm{c}$.

10. Хантингтон С. Третья волна. Демократизация в конце XX века. Москва: РОССПЭН, 2003. 368 с.

11. Шмиттер Ф. К. Будущее демократии : можно ли рассматривать ее через призму масштаба. Логос. 2004. № 2. С. 137-156.

12. Яворський М. Політична стабільність: сутність та основні підходи до класифікації. Політичні науки. 2017.Vol. 3. № 1. С. 61-66.

13. Covington C. Smith E. Dynamics of Democracy. Madison-Sydney: Brown\&Benchmark, 1995.

14. Merkel W. Embedded and Defective Democracies. Democratization. 2004. Vol. 11. № 5. P. 48-49.

\section{Information about the author: Kozminykh A. V.,} $\mathrm{PhD}$ in Political Science, Associate Professor, Associate Professor at the Department of Political Theories of the National University «Odessa Law Academy» 2, Academichna str., Odesa, 65009, Ukriane 